\title{
Effect of saxagliptin on the expression of HIF-1 $\alpha$ in the liver of diabetic rats with fatty liver
}

\author{
QIAN ZHAO, QIAN XIAO, XIANGYING MENG, JIANYANG CHEN, WEIWEI YE and YONG ZHOU \\ Department of Endocrinology, Dahua Hospital of Xuhui District, Shanghai 200237, P.R. China
}

Received March 13, 2018; Accepted July 5, 2018

DOI: $10.3892 /$ etm.2018.6473

\begin{abstract}
The present study was designed to establish a rat model of type 2 diabetes mellitus (T2DM) complicated with fatty liver and to detect the expression of hypoxia-inducible factor-1 $\alpha(\mathrm{HIF}-1 \alpha)$ in liver tissue during the treatment with saxagliptin. Eighty male Wistar rats were randomly divided into two groups. One group was fed with high fat diet to establish T2DM model ( $n=40)$, and the other group was fed normally to serve as the control group $(n=40)$. Successfully established rat T2DM models were randomly divided into two groups: The treatment group that received intraperitoneal injection of saxagliptin solution and the other the model group with normal breeding. Blood glucose, blood lipid, liver function and the expression of HIF-1 $\alpha$ in liver tissue were detected. Levels of blood glucose in model treatment group were significantly higher than those in the control group $(\mathrm{p}<0.05)$. Levels of total cholesterol (TC), triglyceride (TG), low-density lipoprotein cholesterol (LDL-C), high-density lipoprotein cholesterol (HDL-C), aspartate aminotransferase (AST), alanine aminotransferase (ALT) and $\gamma$-glutamyl transferase (GGT) in model and treatment group were significantly higher than those in control group $(\mathrm{p}<0.05)$, but were significantly reduced with the prolonged treatment $(\mathrm{p}<0.05)$. Levels of TC, TG, LDL-C, HDL-C, AST, ALT and GGT and expression level of HIF-1 $\alpha$ were significantly higher in the model group than in control group before 3 weeks of treatment $(\mathrm{p}<0.05)$, but no significant differences were found after 3 weeks of treatment ( $>00.05)$. Expression level of HIF-1 $\alpha$ was decreased with the prolonged treatment, and no significant difference in expression level of HIF-1 $\alpha$ was found 3 weeks after treatment $(\mathrm{p}>0.05)$. In conclusion, HIF-1 $\alpha$ is highly expressed in rats with T2DM and fatty liver. Saxagliptin can effectively improve blood glucose, blood lipid
\end{abstract}

Correspondence to: Dr Yong Zhou, Department of Endocrinology, Dahua Hospital of Xuhui District, 901 Laohumin Road, Shanghai 200237, P.R. China

E-mail: yuxinyi0703@126.com

Key words: diabetes mellitus, fatty liver, hypoxia-inducible factor-1 $\alpha$, saxagliptin and liver function and reduce the protein expression of HIF-1 $\alpha$ in diabetic rats with fatty liver.

\section{Introduction}

With the changes in people's diet structure, such as the popularization of Western-style diet, incidence of type 2 diabetes mellitus (T2DM) shows an increasing trend (1). Zinman et al (2) reported that T2DM affected 3 million patients in 2015. Green et al (3) predicted that the number of patients with T2DM will exceed 5 million in 2030. Presently, T2DM is the most common type of chronic disease worldwide (4). T2DM is a chronic metabolic disorder characterized by insufficient insulin secretion or resistance (5). Complications of T2DM mainly include glucose and lipid metabolism disorder, of which fatty liver is the most common complication (6). At present, there is no radical treatment of T2DM in clinical practice, and conventional treatment can only delay the development of T2DM (7). Hypoxia-inducible factor- $1 \alpha(\mathrm{HIF}-1 \alpha)$ is a protein with critical roles in post-transcriptional and post-transcriptional regulation of gene expression. Studies in recent years (8-10) have shown that HIF-1 $\alpha$ is closely correlated with the onset and development of T2DM, while its involvement in T2DM-induced fatty liver is unclear. Saxagliptin, as a potent inhibitor of dipeptidyl peptidase-4 (DPP-4), can increase the level of endogenous glucagon-like peptide-1 (GLP-1) to regulate blood glucose. In this study, a rat model of T2DM complicated with fatty liver was established and the expression of HIF-1 $\alpha$ in liver tissue during the treatment with saxagliptin was detected. Our study provided new insights for the treatment of T2DM complicated with fatty liver.

\section{Materials and methods}

Animals. Eighty male Wistar rats weighted 170-250 gr were provided by the Experimental Animal Center of Hunan Normal University. Feeding conditions: Room temperature $26^{\circ} \mathrm{C}$, humidity $75 \%$, five rats in one cage, normal light and free access to water. The study was approved by the Ethics Committee of Dahua Hospital of Xuhui District (Shanghai, China).

Model construction. All rats were randomly divided into two groups. One group was subjected to T2DM modeling $(n=40)$ 
and the other group was control $(\mathrm{n}=40)$. Rats in model group were fed with high fat diet $(0.5 \%$ cholic acid, $1 \%$ cholesterol, $15 \%$ lard, $20 \%$ sucrose, $63.5 \%$ basal diet) after 1 week adaptive feeding. After continuous feeding for 4 weeks, intraperitoneal injection of streptozotocin $(30 \mathrm{mg} / \mathrm{kg}$, once a day) was performed. After 8 weeks of feeding, fasting blood glucose, insulin sensitivity index and indexes of liver function were detected. Based on the diagnostic criteria for fatty liver proposed in 2015 (11), fasting blood glucose (>16 mmol/l) and the decrease of insulin sensitivity index were used as the indicators of the successfully established models.

Experimental methods. Successfully established rat T2DM models were randomly divided into two groups: One group was treatment group that received intraperitoneal injection of saxagliptin solution $(10 \mathrm{mg} / \mathrm{kg}$, once per day), the other was a model group with normal breeding. Six mice in each of the three groups were sacrificed at $12 \mathrm{~h}$ after the model construction, 1 and 3 weeks after treatment. Blood $(2 \mathrm{ml})$ was extracted, followed by centrifugation at $3,500 \mathrm{x} \mathrm{g}$ for 5 min. Beckman Coulter AU5800 automatic biochemical analyzer (Beckman Coulter, Inc., Brea, CA, USA) was used to detect blood glucose, blood lipids and liver function indexes. Rat liver was removed and fixed in 10\% neutral formalin. Expression of HIF-1 $\alpha$ protein in liver tissue was detected by western blot analysis.

Western blot analysis. After total protein extraction, $10 \%$ PAGE gel electrophoresis was performed, followed by transmembrane under $100 \mathrm{~V}$ for $2 \mathrm{~h}$. After blocking for $1 \mathrm{~h}$ at room temperature, membranes were incubated with rabbit monoclonal HIF- $\alpha$ antibody (cat. no. ab51608; dilution 1:250) overnight, followed by incubation with secondary goat anti-rabbit (HRP) IgG antibody (cat. no. ab6721; dilution 1:1000) for $1-2 \mathrm{~h}$ at room temperature. All the antibodies were all purchased from Abcam (Cambridge, MA, USA). Test was in accordance with BD's test kit instructions (BD Biosciences, Franklin Lakes, NJ, USA).

Observation indicators. Blood glucose, triglyceride (TG), total cholesterol (TC), high-density lipoprotein cholesterol (HDL-C), low-density lipoprotein cholesterol (LDL-C); liver function indexes: Alanine aminotransferase (ALT), aspartate aminotransferase (AST), $\gamma$-glutamyl transferase (GGT); HIF-1 $\alpha$ protein expression.

Statistical analysis. SPSS 22.0 statistical software (IBM Corp., Armonk, NY, USA) was used for all statistical analyses. Enumeration data are expressed as rate and processed using Chi-square test. Measurement data are expressed as mean \pm standard deviation, and comparisons among multiple groups and between two groups were performed by analysis of variance followed by Least Significant Difference as its post hoc test and t-test, respectively. $\mathrm{P}<0.05$ indicates a difference with statistical significance.

\section{Results}

Results of model construction. Thirty-seven model rats were successfully established, and success rate was $92.5 \%$ (37/40).

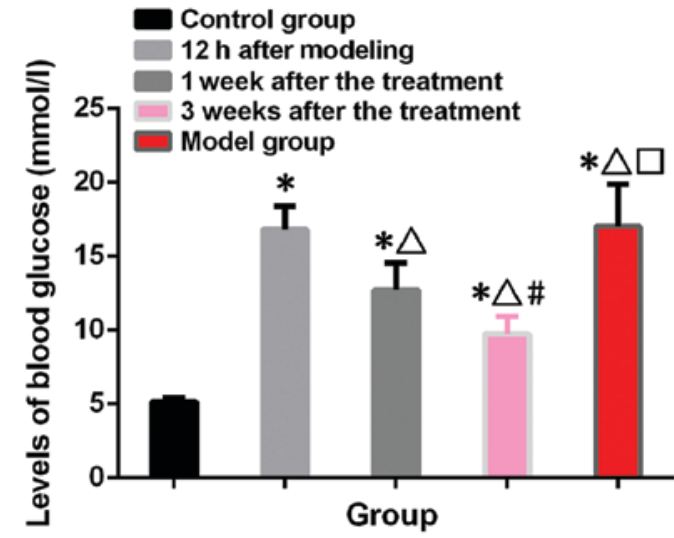

Figure 1. Blood glucose test results of two groups of rats. There was no significant difference between model and treatment group at $12 \mathrm{~h}$ after model construction. Levels of blood glucose in model and treatment group were significantly higher than those in control group at $12 \mathrm{~h}$ after model construction, and 1 and 3 weeks after treatment. In treatment group, blood glucose gradually decreased with the prolonged treatment. ${ }^{*} \mathrm{p}<0.05$, compared with control group; ${ }^{\wedge} \mathrm{p}<0.05$, compared with $12 \mathrm{~h}$ after model construction; ${ }^{\#} \mathrm{p}<0.05$, compared with 1 week after treatment; ${ }^{\square} \mathrm{p}<0.05$, compared with 3 weeks after treatment.

Those rat models were randomly divided into treatment group $(n=19)$ and model group $(n=18)$.

Blood glucose test results. Blood glucose in control group was $5.16 \pm 0.24 \mathrm{mmol} / \mathrm{l}$, and blood glucose in model group was $17.04 \pm 2.82 \mathrm{mmol} / 1$. Blood glucose levels in treatment group at $12 \mathrm{~h}$ after model construction, 1 and 3 weeks after treatment were $16.82 \pm 2.56,12.72 \pm 1.84$ and $9.73 \pm 1.18 \mathrm{mmol} / 1$, respectively. Levels of blood glucose in model and treatment group were significantly higher than those in control group $(\mathrm{p}<0.05)$. There was no significant difference between model and treatment group at $12 \mathrm{~h}$ after model construction ( $p>0.05)$. Blood glucose level 3 weeks after treatment were lower than those 1 week after treatment $(\mathrm{p}<0.05)($ Fig. 1$)$.

Blood lipid test results. Levels of TC, TG, LDL-C and HDL-C in treatment and model group were significantly higher than those in control group $(\mathrm{p}<0.05)$. After treatment, levels of TC, TG, LDL-C and HDL-C in treatment group gradually decreased $(\mathrm{p}<0.05)$ (Table I).

Liver function test results. Levels of AST, ALT and GGT in treatment and model group were significantly higher than those in control group $(\mathrm{p}<0.05)$. After treatment, levels of AST, ALT and GGT in rats of treatment group gradually decreased $(\mathrm{p}<0.05)$ (Table II).

HIF-1 $\alpha$ test results. Relative HIF-1 $\alpha$ expression level was $0.40 \pm 0.01$ in control group and $1.30 \pm 0.30$ in the model group. Relative HIF-1 $\alpha$ expression level was $1.24 \pm 0.14$ in treatment group at $12 \mathrm{~h}$ after model construction, $0.86 \pm 0.10$ at 1 week after treatment and $0.41 \pm 0.03$ at 3 weeks after treatment. Expression level of HIF-1 $\alpha$ was significantly higher in model and treatment group than in control group at $12 \mathrm{~h}$ after model construction and 1 week after treatment $(p<0.05)$. No significant differences in the expression level of HIF-1 $\alpha$ were found between model and treatment group at $12 \mathrm{~h}$ after 
Table I. Blood lipid test results of two groups of rats (mmol/l).

\begin{tabular}{|c|c|c|c|c|c|}
\hline \multirow[b]{2}{*}{ Items } & \multirow[b]{2}{*}{ Control group } & \multicolumn{3}{|c|}{ Treatment group } & \multirow[b]{2}{*}{ Model group } \\
\hline & & $\begin{array}{l}12 \mathrm{~h} \text { after } \\
\text { model construction }\end{array}$ & $\begin{array}{c}1 \text { week } \\
\text { after treatment }\end{array}$ & $\begin{array}{c}3 \text { weeks } \\
\text { after treatment }\end{array}$ & \\
\hline $\mathrm{TC}$ & $0.32 \pm 0.24$ & $4.48 \pm 1.27^{\mathrm{a}}$ & $3.54 \pm 0.94^{\mathrm{a}, \mathrm{b}}$ & $1.92 \pm 0.76^{\mathrm{a}-\mathrm{c}}$ & $4.52 \pm 1.36^{\mathrm{a}-\mathrm{d}}$ \\
\hline TG & $0.61 \pm 0.25$ & $1.52 \pm 0.92^{\mathrm{a}}$ & $1.14 \pm 0.46^{\mathrm{a}, \mathrm{b}}$ & $0.89 \pm 0.24^{\mathrm{a}-\mathrm{c}}$ & $1.61 \pm 0.87^{\mathrm{a}-\mathrm{d}}$ \\
\hline LDL-C & $0.24 \pm 0.10$ & $2.08 \pm 1.09^{\mathrm{a}}$ & $1.52 \pm 0.86^{\mathrm{a}, \mathrm{b}}$ & $0.96 \pm 0.31^{\mathrm{a}-\mathrm{c}}$ & $2.04 \pm 1.02^{\mathrm{a}-\mathrm{d}}$ \\
\hline HDL-C & $1.04 \pm 0.24$ & $2.28 \pm 0.53^{\mathrm{a}}$ & $1.83 \pm 0.47^{\mathrm{a}, \mathrm{b}}$ & $1.37 \pm 0.56^{\mathrm{a}-\mathrm{c}}$ & $2.20 \pm 0.41^{\mathrm{a}-\mathrm{d}}$ \\
\hline
\end{tabular}

${ }^{\mathrm{a}} \mathrm{P}<0.05$, compared with control group; ${ }^{\mathrm{b}} \mathrm{p}<0.05$, compared with $12 \mathrm{~h}$ after model construction; ${ }^{\mathrm{c}} \mathrm{p}<0.05$, compared with $1 \mathrm{week}$ after treatment; ${ }^{\mathrm{d}} \mathrm{p}<0.05$, compared with 3 weeks after treatment. TC, total cholesterol; TG, triglyceride; LDL-C, low-density lipoprotein cholesterol; HDL-C, high-density lipoprotein cholesterol.

Table II. Liver function test results of two groups of rats (IU/l).

\begin{tabular}{|c|c|c|c|c|c|}
\hline \multirow[b]{2}{*}{ Items } & \multirow[b]{2}{*}{ Control group } & \multicolumn{3}{|c|}{ Treatment group } & \multirow[b]{2}{*}{ Model group } \\
\hline & & $\begin{array}{c}12 \mathrm{~h} \text { after } \\
\text { model construction }\end{array}$ & $\begin{array}{c}1 \text { week } \\
\text { after treatment }\end{array}$ & $\begin{array}{c}3 \text { weeks } \\
\text { after treatment }\end{array}$ & \\
\hline AST & $18.25 \pm 4.51$ & $36.34 \pm 6.27^{\mathrm{a}}$ & $30.69 \pm 4.01^{\mathrm{a}, \mathrm{b}}$ & $24.36 \pm 5.83^{\mathrm{a}-\mathrm{c}}$ & $35.84 \pm 6.04^{\mathrm{a}-\mathrm{d}}$ \\
\hline ALT & $24.43 \pm 4.92$ & $37.42 \pm 8.22^{\mathrm{a}}$ & $33.14 \pm 7.16^{\mathrm{a}, \mathrm{b}}$ & $28.77 \pm 6.04^{\mathrm{a}-\mathrm{c}}$ & $36.62 \pm 8.04^{\mathrm{a}-\mathrm{d}}$ \\
\hline GGT & $27.15 \pm 6.27$ & $42.52 \pm 9.81^{\mathrm{a}}$ & $38.05 \pm 4.37^{\mathrm{a}, \mathrm{b}}$ & $34.53 \pm 6.98^{\mathrm{a}-\mathrm{c}}$ & $41.60 \pm 9.70^{a-d}$ \\
\hline
\end{tabular}

${ }^{a} \mathrm{P}<0.05$, compared with control group; ${ }^{\mathrm{b}} \mathrm{p}<0.05$, compared with $12 \mathrm{~h}$ after model construction; ${ }^{\mathrm{c}} \mathrm{p}<0.05$, compared with 1 week after treatment; ${ }^{\mathrm{d}} \mathrm{p}<0.05$, compared with 3 weeks after treatment. AST, aspartate aminotransferase; ALT, alanine aminotransferase; GGT, $\gamma$-glutamyl transferase.

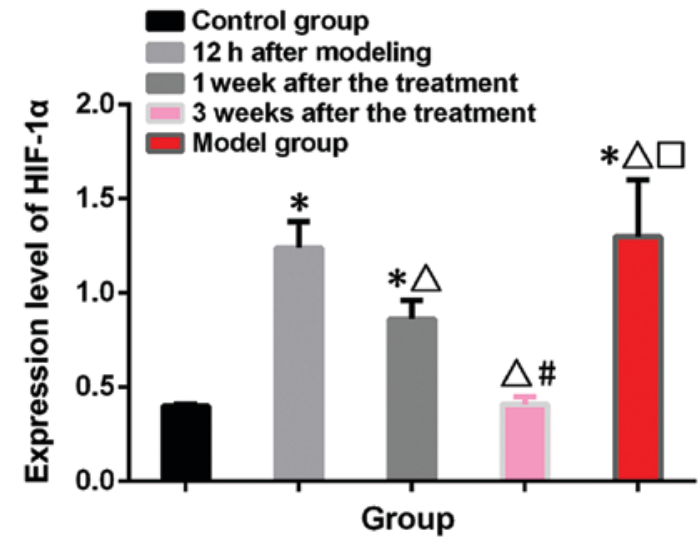

Figure 2. HIF-1 $\alpha$ test results of two groups of rats. There was no significant difference between model and treatment group at $12 \mathrm{~h}$ after model construction. Expression level of HIF-1 $\alpha$ was significantly higher in model and treatment group at $12 \mathrm{~h}$ after model construction and 1 week after treatment. In treatment group, expression level of HIF-1 $\alpha$ decreased with the prolonged treatment, and no significant differences in expression level of HIF-1 $\alpha$ were found between treatment and control group at 3 weeks after treatment. ${ }^{*} \mathrm{p}<0.05$, compared with control group; ${ }^{\circ} \mathrm{p}<0.05$, compared with model group at $12 \mathrm{~h}$ after model construction; ${ }^{\#} \mathrm{p}<0.05$, compared with 1 week after treatment; ${ }^{\square} \mathrm{p}<0.05$, compared with 3 weeks after treatment. HIF- $1 \alpha$, hypoxia-inducible factor- $1 \alpha$.

model construction $(\mathrm{p}>0.05)$. In treatment group, the expression level of HIF-1 $\alpha$ decreased with the prolonged treatment, and no significant differences in expression level of HIF-1 $\alpha$ were found between treatment and control group 3 weeks after treatment ( $\mathrm{p}>0.05)$ (Fig. 2).

\section{Discussion}

T2DM can easily lead to damage of important organs in human body and has been proved to be a major cause of a variety of heart, brain, liver and eye diseases (12). At present, there is no clear conclusion on the pathogenesis of T2DM-induced fatty liver disease. Insulin resistance and oxidative stress lipid peroxidation is a major cause of inflammatory necrosis and fibrosis in the liver $(13,14)$. HIF-1, a DNA-binding protein discovered by Semenza and Wang (15) in 1992, is composed of two subunits, $\alpha$ and $\beta$, and has been shown to have various immune responses in the human body through hypoxic-ischemic conditions $(16,17)$. The role of HIF-1 in patients with T2DM complicated with fatty liver is unclear. In this study, rats T2DM and fatty liver models were induced by high-fat diet and treated with saxagliptin. The expression of HIF-1 $\alpha$ was detected to examine the role of HIF-1 $\alpha$ in T2DM and fatty liver.

In this study, compared with control group, the expression level of HIF-1 $\alpha$ in model group was significantly higher than that in control group, and the expression levels of HIF-1 $\alpha$ in rat models were decreased gradually with the prolonged saxagliptin treatment and reached the level of control group 3 weeks after treatment, indicating the involvement of HIF-1 $\alpha$ in the onset and development of T2DM, which is consistent 
with the findings of Nayak et al (18). The possible explanation is that HIF-1 $\alpha$ promotes the transcription of VEGF under the condition of hypoxia, so as to induce the regeneration of liver cells in rats with fatty liver (19). Over-proliferation of cells accelerates the consumption of oxygen in rats, and the internal circulatory system cannot provide enough oxygen, which in turn induces the expression of HIF-1 $\alpha$, resulting in a vicious circle. HIF-1 $\alpha$ stimulates the secretion of a large number of cellular stimulating factors, so as to exacerbate insulin secretion and reduce insulin sensitivity, thus contributing to the development of fatty liver (20). Saxagliptin can also effectively improve blood glucose and lipids and liver function by improving insulin resistance metabolic disorders (21). With the prolonged treatment, those indexes gradually decreased, indicating that saxagliptin can effectively improve the blood glucose, blood lipid and liver function. Insulin resistance induces the synthesis of free fatty acids in adipose tissue, which can result in elevation of GLP-1 in rats, leading to further deterioration of fatty liver (22). Overload of GLP-1 directly affects the normal metabolic function of the digestive system of rats and greatly reduces the absorption of nutrients. Saxagliptin increases the synthesis and metabolism of cyclic adenosine monophosphate and inhibits the secretion of glucagon, which can not only promote the proliferation and differentiation of $\beta$ cells, but also activate the protective effect of GLP-1 receptor on liver of rats (23). Therefore, re-deterioration of liver cirrhosis in rats was suppressed. With saxagliptin, insulin in rats is effectively maintained and the activation of VEGF is inhibited, resulting in gradually decreased expression level of HIF-1 $\alpha$.

In this study, upregulated expression of HIF-1 $\alpha$ was observed in diabetic rats combined with fatty liver and saxagliptin effectively inhibited the expression of HIF-1 $\alpha$. However, animal system may be different from human body. Therefore, clinical studies are needed to further confirm our conclusions.

In conclusion, HIF-1 $\alpha$ is highly expressed in rats with T2DM and fatty liver. Saxagliptin can effectively improve the blood glucose, blood lipid and liver function, and reduce the expression level of HIF-1 $\alpha$ protein.

\section{Acknowledgements}

Not applicable.

\section{Funding}

This study was funded by the Medical Science Program of Xuhui District (no. SHXH201427; Shanghai, China).

\section{Availability of data and materials}

The datasets used and/or analyzed during the present study are available from the corresponding author on reasonable request.

\section{Authors' contributions}

QZ was responsible for writing the manuscript and model construction. QX and XM analyzed and interpreted blood lipid results and blood glucose tests. JC performed liver function test. WY helped with HIF-1 $\alpha$ test. YZ performed western blot analysis. All authors read and approved the final manuscript.

\section{Ethics approval and consent to participate}

The study was approved by the Ethics Committee of Dahua Hospital of Xuhui District (Shanghai, China).

\section{Consent for publication}

Not applicable.

\section{Competing interests}

The authors declare that they have no competing interests.

\section{References}

1. American Diabetes Association: Standards of medical care in diabetes-2017 abridged for primary care providers. Clin Diabetes 35: 5-26, 2017.

2. Zinman B, Wanner C, Lachin JM, Fitchett D, Bluhmki E, Hantel S, Mattheus M, Devins T, Johansen OE, Woerle HJ, et al; EMPA-REG OUTCOME Investigators: Empagliflozin, cardiovascular outcomes, and mortality in type 2 diabetes. N Engl J Med 373: 2117-2128, 2015.

3. Green JB, Bethel MA, Armstrong PW, Buse JB, Engel SS, Garg J, Josse R, Kaufman KD, Koglin J, Korn S, et al; TECOS Study Group: Effect of sitagliptin on cardiovascular outcomes in type 2 diabetes. N Engl J Med 373: 232-242, 2015.

4. American Diabetes Association: 2. Classification and diagnosis of diabetes. Diabetes Care 40 (Suppl 1): S11-S24, 2017.

5. Marso SP, Daniels GH, Brown-Frandsen K, Kristensen P, Mann JF, Nauck MA, Nissen SE, Pocock S, Poulter NR, Ravn LS, et al; LEADER Steering Committee; LEADER Trial Investigators: Liraglutide and cardiovascular outcomes in type 2 Diabetes. N Engl J Med 375: 311-322, 2016.

6. Byrne CD and Targher G: EASL-EASD-EASO Clinical Practice Guidelines for the management of non-alcoholic fatty liver disease: Is universal screening appropriate? Diabetologia 59: 1141-1144, 2016.

7. Cheung O, Kapoor A, Puri P, Sistrun S, Luketic VA, Sargeant CC, Contos MJ, Shiffman ML, Stravitz RT, Sterling RK, et al: The impact of fat distribution on the severity of nonalcoholic fatty liver disease and metabolic syndrome. Hepatology 46: 1091-1100, 2007.

8. Mehrabani M, Najafi M, Kamarul T, Mansouri K, Iranpour M, Nematollahi MH, Ghazi-Khansari $M$ and Sharifi AM: Deferoxamine preconditioning to restore impaired HIF-1 $\alpha$-mediated angiogenic mechanisms in adipose-derived stem cells from STZ-induced type 1 diabetic rats. Cell Prolif 48: 532-549, 2015.

9. Chen H, Jia P, Kang H, Zhang H, Liu Y, Yang P, Yan Y, Zuo G, Guo L, Jiang M, et al: Upregulating HIF-1 $\alpha$ by hydrogel nanofibrous scaffolds for rapidly recruiting angiogenesis relative cells in diabetic wound. Adv Healthc Mater 5: 907-918, 2016.

10. Sunkari VG, Lind F, Botusan IR, Kashif A, Liu ZJ, Ylä-Herttuala S, Brismar K, Velazquez O and Catrina SB: Hyperbaric oxygen therapy activates hypoxia-inducible factor 1 (HIF-1), which contributes to improved wound healing in diabetic mice. Wound Repair Regen 23: 98-103, 2015.

11. Lonardo A, Ballestri S, Marchesini G, Angulo P and Loria P: Nonalcoholic fatty liver disease: A precursor of the metabolic syndrome. Dig Liver Dis 47: 181-190, 2015.

12. Oei L, Rivadeneira F, Zillikens MC and Oei EH: Diabetes, diabetic complications, and fracture risk. Curr Osteoporos Rep 13: 106-115, 2015.

13. Asrih M and Jornayvaz FR: Metabolic syndrome and nonalcoholic fatty liver disease: Is insulin resistance the link? Mol Cell Endocrinol 418: 55-65, 2015.

14. Chen S, Zhao X, Ran L, Wan J, Wang X, Qin Y, Shu F, Gao Y, Yuan L, Zhang Q, et al: Resveratrol improves insulin resistance, glucose and lipid metabolism in patients with non-alcoholic fatty liver disease: A randomized controlled trial. Dig Liver Dis 47: 226-232, 2015 
15. Semenza GL and Wang GL: A nuclear factor induced by hypoxia via de novo protein synthesis binds to the human erythropoietin gene enhancer at a site required for transcriptional activation. Mol Cell Biol 12: 5447-5454, 1992.

16. Balamurugan K: HIF-1 at the crossroads of hypoxia, inflammation, and cancer. Int J Cancer 138: 1058-1066, 2016.

17. Zhang H, Lu H, Xiang L, Bullen JW, Zhang C, Samanta D, Gilkes DM, He J and Semenza GL: HIF-1 regulates CD47 expression in breast cancer cells to promote evasion of phagocytosis and maintenance of cancer stem cells. Proc Natl Acad Sci USA 112: E6215-E6223, 2015.

18. Nayak BK, Shanmugasundaram K, Friedrichs WE, Cavaglierii RC, Patel M, Barnes J and Block K: HIF-1 mediates renal fibrosis in OVE26 type 1 diabetic mice. Diabetes 65: 1387-1397, 2016

19. Dodd KM, Yang J, Shen MH, Sampson JR and Tee AR: mTORC1 drives HIF-1 $\alpha$ and VEGF-A signalling via multiple mechanisms involving 4E-BP1, S6K1 and STAT3. Oncogene 34: 2239-2250, 2015.

20. Rigiracciolo DC, Scarpelli A, Lappano R, Pisano A, Santolla MF, De Marco P, Cirillo F, Cappello AR, Dolce V, Belfiore A, et al: Copper activates HIF-1 $\alpha /$ GPER/VEGF signalling in cancer cells. Oncotarget 6: 34158-34177, 2015.
21. Toh S, Hampp C, Reichman ME, Graham DJ, Balakrishnan S, Pucino F, Hamilton J, Lendle S, Iyer A, Rucker M, et al: Risk for hospitalized heart failure among new users of saxagliptin, sitagliptin, and other antihyperglycemic drugs: A retrospective cohort study. Ann Intern Med 164: 705-714, 2016.

22. Armstrong MJ, Gaunt P, Aithal GP, Barton D, Hull D, Parker R, Hazlehurst JM, Guo K, Abouda G, Aldersley MA, et al; LEAN trial team: Liraglutide safety and efficacy in patients with non-alcoholic steatohepatitis (LEAN): A multicentre, double-blind, randomised, placebo-controlled phase 2 study. Lancet 387: 679-690, 2016.

23. Dyson JK, Anstee QM and McPherson S: Non-alcoholic fatty liver disease: A practical approach to treatment. Frontline Gastroenterol 5: 277-286, 2014.

(c) (i) (9) This work is licensed under a Creative Commons cC) Attribution-NonCommercial-NoDerivatives 4.0 International (CC BY-NC-ND 4.0) License. 